Review

\title{
Intercellular Signaling Pathway among Endothelia, Astrocytes and Neurons in Excitatory Neuronal Damage
}

Takako Takemiya $^{1, *}$ and Kanato Yamagata ${ }^{2}$

1 Medical Research Institute, Tokyo Women's Medical University, Shinjuku, Tokyo 162-8666, Japan

2 Neural Plasticity Project, Tokyo Metropolitan Institute of Medical Science, Tokyo 156-8506, Japan; E-Mail: yamagata-kn@igakuken.or.jp

* Author to whom correspondence should be addressed; E-Mail: takakot@lab.twmu.ac.jp; Tel.: +81-3-3353-8111; Fax: +81-3-5269-7454.

Received: 1 February 2013; in revised form: 20 March 2013 / Accepted: 3 April 2013 /

Published: 16 April 2013

\begin{abstract}
Neurons interact closely with astrocytes via glutamate; this neuron-glia circuit may play a pivotal role in synaptic transmission. On the other hand, astrocytes contact vascular endothelial cells with their end-feet. It is becoming obvious that non-neuronal cells play a critical role in regulating the neuronal activity in the brain. We find that kainic acid (KA) administration induces the expression of microsomal prostaglandin E synthase-1 (mPGES-1) in venous endothelial cells and the prostaglandin $\mathrm{E}_{2}\left(\mathrm{PGE}_{2}\right)$ receptor prostaglandin E receptor (EP)-3 on astrocytes. Endothelial mPGES-1 exacerbates KA-induced neuronal damage in in vivo experiments. In in vitro experiments, mPGES-1 produces $\mathrm{PGE}_{2}$, which enhances astrocytic $\mathrm{Ca}^{2+}$ levels via the EP3 receptor and increases $\mathrm{Ca}^{2+}$-dependent glutamate release, thus aggravating neuronal injury. This novel endothelium-astrocyte-neuron signaling pathway may be crucial for driving neuronal damage after repetitive seizures and could be a new therapeutic target for epilepsy and other brain disorders.
\end{abstract}

Keywords: microsomal prostaglandin E synthase-1 (mPGES-1); prostaglandin $\mathrm{E}_{2}\left(\mathrm{PGE}_{2}\right)$; endothelial cell; EP3; kainic acid; $\mathrm{Ca}^{2+}$ levels; astrocyte; neuronal damage 


\section{Introduction}

Prostaglandin $\mathrm{E}_{2}\left(\mathrm{PGE}_{2}\right)$ is one of the most important modulators in inflammation. In the brain, $\mathrm{PGE}_{2}$ is also involved in pathological processes, such as fever, seizure and cerebral ischemia [1-3], suggesting that these processes might be associated with inflammation. $\mathrm{PGE}_{2}$ is sequentially synthesized from arachidonic acid by cyclooxygenase (COX) and $\mathrm{PGE}_{2}$ synthase (PGES) in various cells and tissues. COX catalyzes the first step in the synthesis of prostaglandins (PGs) and exists in two homologous isoforms. One isoform is the constitutively active COX-1, which is widely distributed in various cell types and is thought to mediate physiological responses. The other isoform is the inducible COX-2, which is expressed in several cell types in response to various stimuli, such as neuronal activity, cytokines and pro-inflammatory molecules [4-8]. Inducible COX-2 expression in the brain is associated with acute neurotoxicity, such as seizures and ischemia [2,3,9,10]. COX-2 is also involved in delayed pro-inflammatory activities, which aggravate the neuronal damage found in neurodegenerative diseases, such as amyotrophic lateral sclerosis (ALS), Parkinson's disease (PD), multiple sclerosis (MS) and Alzheimer's disease (AD) [9,11]. We find that COX-2 is induced in non-neuronal cells late after seizure and facilitates neuronal loss in the hippocampus [12].

In this review, we first focus on the co-induction of COX-2 and microsomal prostaglandin $\mathrm{E}$ synthase-1 (mPGES-1), an enzyme downstream of COX-2, in brain endothelial cells after seizures. Next, we provide a view on the role of endothelial mPGES-1 in neuronal loss in the hippocampus. Finally, we will present a novel mechanism for exacerbation of neuronal damage by $\mathrm{PGE}_{2}$ derived from endothelial mPGES-1 and discuss the intercellular signaling pathway among endothelia, astrocytes and neurons in this process.

\section{Role of Endothelial mPGES-1 in KA-Induced Neuronal Damage}

\subsection{Co-Induction of COX-2 and mPGES-1 in Brain Endothelial Cells}

We were the first to demonstrate that $\mathrm{PGE}_{2}$ is synthesized by mPGES-1 coupling with COX-2 in brain endothelial cells in lipopolysaccharide (LPS)-induced fever [13], and subsequent publications have confirmed that mPGES-1 is co-induced with COX-2 during fever or inflammation [14-17]. Furthermore, mPGES-1 is induced in the hippocampus after epileptic seizures caused by kainic acid (KA) microinjection. KA is an analogue of the excitatory amino acid glutamate and is suited for research to investigate the mechanisms for hippocampal neuronal loss after seizures, because KA induces generalized convulsion and causes neuronal damage in the hippocampus several days after seizures [18]. Unilateral KA microinjection causes neuronal loss in the injection side, but not in the contralateral side (Figure 1A-C) [12]. Kainate induces mPGES-1 mRNA in the veins, but not in the arteries, neurons or other cells on the ipsilateral side (Figure 1D) or in any cells on the contralateral side (Figure 1E), at 8h after KA microinjection [19]. The mPGES-1 protein is localized in the structure of blood vessel, but not in other cells, such as neurons or glial cells, $24 \mathrm{~h}$ after KA injection (Figure 2A,B) [19]. Double-immunostaining for both mPGES-1 and von Willebrand (v.W.) factor (an endothelial cell marker) shows that mPGES-1 is induced in endothelial cells (Figure 2C). In addition, the co-induction of mPGES- 1 and COX-2 in the endothelial cells was found to continue up to $48 \mathrm{~h}$ after the microinjection (Figure 2D) [19]. 
Figure 1. Neuronal injury elicited by kainic acid (KA) and microsomal prostaglandin E synthase-1 (mPGES-1) mRNA induction in the hippocampus following KA microinjection (summarized from ref. [12] and [19]). (A) Placement of cannula tips for microinjection into the hippocampal CA3 region. (B and $\mathbf{C}$ ) KA-injected hippocampus showing marked cell loss in the ipsilateral side of the CA3 region $(\mathbf{B})$, but little cell loss in the contralateral side (C). Scale bars: $400 \mu \mathrm{m}$. (D and E) mPGES-1 mRNA levels were increased in the veins (arrowheads), but not in the arteries (arrows), neurons (asterisks) or other cells on the ipsilateral side (D) or in any cells on the contralateral side (E) at $8 \mathrm{~h}$ after KA injection. Scale bars: $20 \mu \mathrm{m}$.

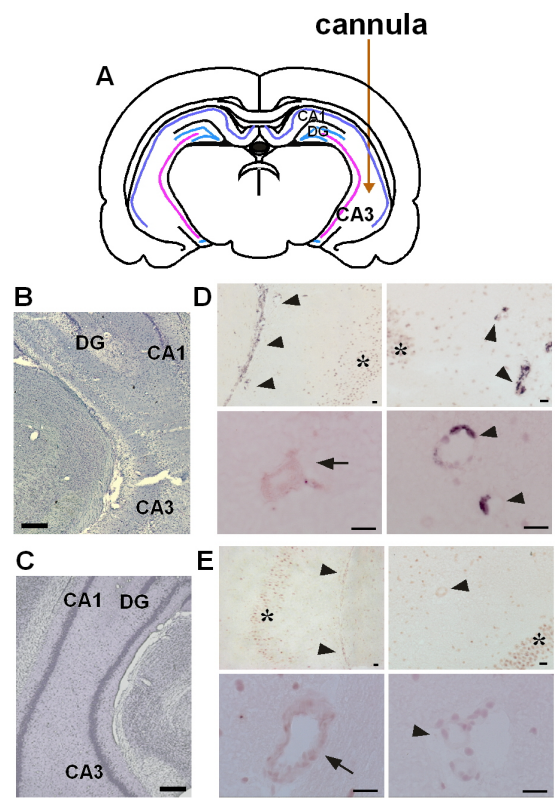

Figure 2. Induction of the mPGES-1 protein in the hippocampus following KA microinjection (summarized from ref. [19]). (A and B) Immunostaining of the mPGES-1 protein in the hippocampal CA3 region at $24 \mathrm{~h}$ after KA (A) or PBS (B) injection. mPGES-1 appeared in the veins (arrowheads), but not in the CA3 neurons (asterisks). (C) Double immunostaining of mPGES-1 and von Willebrand (v.W.) factor at $8 \mathrm{~h}$ and $48 \mathrm{~h}$ after KA treatment; (D) Double immunostaining for COX-2 and mPGES-1 at $24 \mathrm{~h}$ and $48 \mathrm{~h}$ after KA injection. Scale bars: $100 \mu \mathrm{m}$.

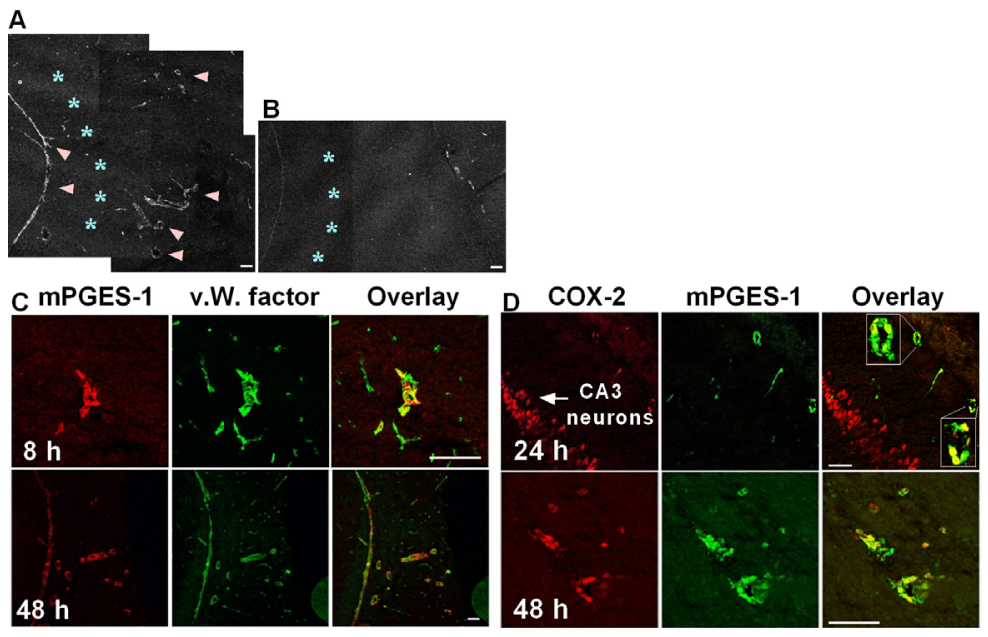




\subsection{Role of Endothelial mPGES-1 in Hippocampal Neuronal Loss}

We also addressed whether mPGES-1 has an effect on neuronal death after KA-induced seizure by using $m P G E S-1^{--}$mice [20]. Our results revealed that endothelial mPGES-1 is a key enzyme for the production of $\mathrm{PGE}_{2}$ (Figure 3A), which stimulates neuronal cell death (Figure 3B,C) [19]. Although it is widely thought that brain $\mathrm{PGE}_{2}$ is synthesized in and derived from astrocytes [21-23], microglia [24] and neurons [25], we found that most brain $\mathrm{PGE}_{2}$, which affects neuronal death, is supplied by endothelial mPGES-1. These findings raise the question of how endothelial $\mathrm{PGE}_{2}$ regulates neuronal damage. Next, we propose a mechanism for the stimulating role of endothelial $\mathrm{PGE}_{2}$ in neuronal death and then verify our hypothesis step by step.

Figure 3. Inducible mPGES-1 produces prostaglandin $\mathrm{E}_{2}\left(\mathrm{PGE}_{2}\right)$ and stimulates neuronal damage (summarized from ref. [19]). (A) $\mathrm{PGE}_{2}$ concentration in the hippocampi of wild-type (WT) mice $(n=6-8)$ and $m P G E S-1^{-/-}$mice $(n=6-8)$ following KA injection; (B) Under naive conditions, there was no significant difference in neuronal density between the WT $(n=7)$ and $m P G E S-1^{-/}$mice $(n=6)$, whereas a significant difference was observed in the number of neurons between the WT $(n=7)$ and $m P G E S-1^{-/}$mice $(n=7)$ at $48 \mathrm{~h}$ after KA microinjection; (C) Nissl staining of the hippocampal CA3 region of the WT (left) and $m P G E S-1^{-/-}$mice (right) at $48 \mathrm{~h}$ after KA microinjection. * $p<0.01$, $* * p<0.005$, Scale bars: $100 \mu \mathrm{m}$.

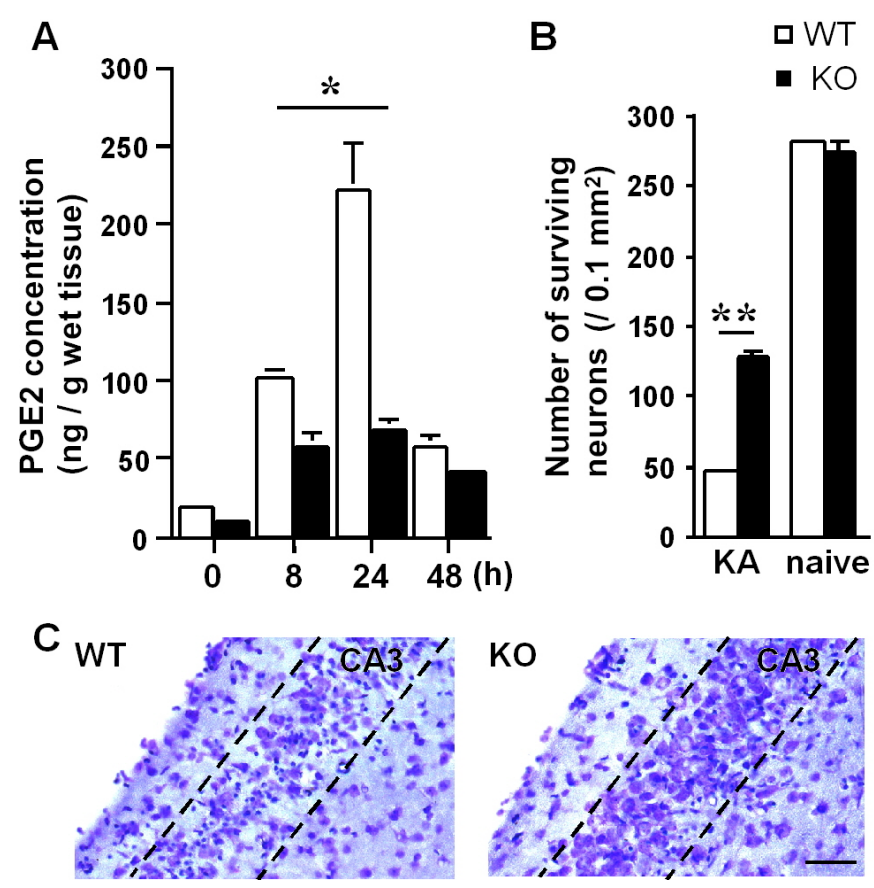

\section{Mechanism for Exacerbation of Neuronal Damage by Endothelial mPGES-1}

\subsection{Hypothetical Mechanism for Exacerbation by mPGES-1}

Brain endothelial cells are surrounded by astrocytic end-feet [26], suggesting that the $\mathrm{PGE}_{2}$ produced in endothelial cells may have a direct effect on the adjacent astrocytes. Several lines of evidence indicate that prostaglandin E receptor (EP) receptors are present on cultured astrocytes. In 
addition, exogenous $\mathrm{PGE}_{2}$ immediately evokes $\mathrm{Ca}^{2+}$-dependent glutamate release from astrocytes [27]; therefore, astrocytes may be activated by endogenous $\mathrm{PGE}_{2}$ to elevate the intracellular $\mathrm{Ca}^{2+}\left(\left[\mathrm{Ca}^{2+}\right]_{\mathrm{i}}\right)$ levels directly through the $\mathrm{PGE}_{2}$ receptor. Moreover, astrocytes can modulate synaptic transmission through the release of glutamate [28-30], which may play a crucial role in delayed neuronal injury after seizures [31]. Taken together, we hypothesize that the endothelial PGE $_{2}$ produced by mPGES-1 directly activates EP receptors on astrocytes, elevating the astrocytic $\left[\mathrm{Ca}^{2+}\right]_{i}$ levels and, subsequently, evoking sustained glutamate release, ultimately leading to neuronal damage. To investigate the mechanisms of the neuronal damage while maintaining the intercellular associations among endothelial cells, astrocytes and neurons, we used hippocampal slice culture prepared from wild-type (WT) and $m P G E S-1^{-/-}$mice.

\subsection{Increases in Hippocampal PGE $E_{2}$ Concentration and Astrocytic $\mathrm{Ca}^{2+}$ Levels after KA Treatment}

First, we treated the WT hippocampal slices with KA, which significantly elevated the $\mathrm{PGE}_{2}$ concentration in the slices. This increase in $\mathrm{PGE}_{2}$ was not observed in the $m P G E S-1^{-/}$slices (Figure $4 \mathrm{~A})$. Next, we labeled $\left[\mathrm{Ca}^{2+}\right]_{\mathrm{i}}$ and astrocytes in the slices with Fluo-4 $\left(\mathrm{Ca}^{2+}\right.$ indicator) and sulforhodamine101 (SR101; astrocyte marker), respectively (Figure 4B), and counted the number of astrocytes with elevated $\left[\mathrm{Ca}^{2+}\right]_{\mathrm{i}}$ levels within a set rectangular area of the hippocampal CA3 region (Figure 4C). The number of these cells within the rectangular area was significantly smaller in the $m P G E S-1^{-/}$slices (Figure 4D, right panel) than in the WT slices (Figure 4D, left panel and Figure 4E). These results suggest that the $\mathrm{PGE}_{2}$ derived from mPGES-1 upregulates the astrocytic $\left[\mathrm{Ca}^{2+}\right]_{\mathrm{i}}$ levels in the hippocampus, especially in the $\mathrm{CA} 3$ region.

Figure 4. KA-induced mPGES-1 produces $\mathrm{PGE}_{2}$ and increases the astrocytic $\mathrm{Ca}^{2+}$ levels, promoting glutamate release from astrocytes and causing neuronal damage (summarized from ref. [32]). (A) $\mathrm{PGE}_{2}$ concentrations in cultured slices from WT and $m P G E S-1^{-/-}$mice after the addition of KA or PBS for $17 \mathrm{~h}(n=5-6)$; (B) $\mathrm{Ca}^{2+}$ imaging in the WT (left) and $m P G E S-1^{-/-}$slices (right); (C) The number of Fluo-4 labeled astrocytes within the rectangular areas in WT and $m P G E S-1^{-/-}$slices treated with KA or PBS $(n=5)$. $* p<0.001, * * p<0.0001$.
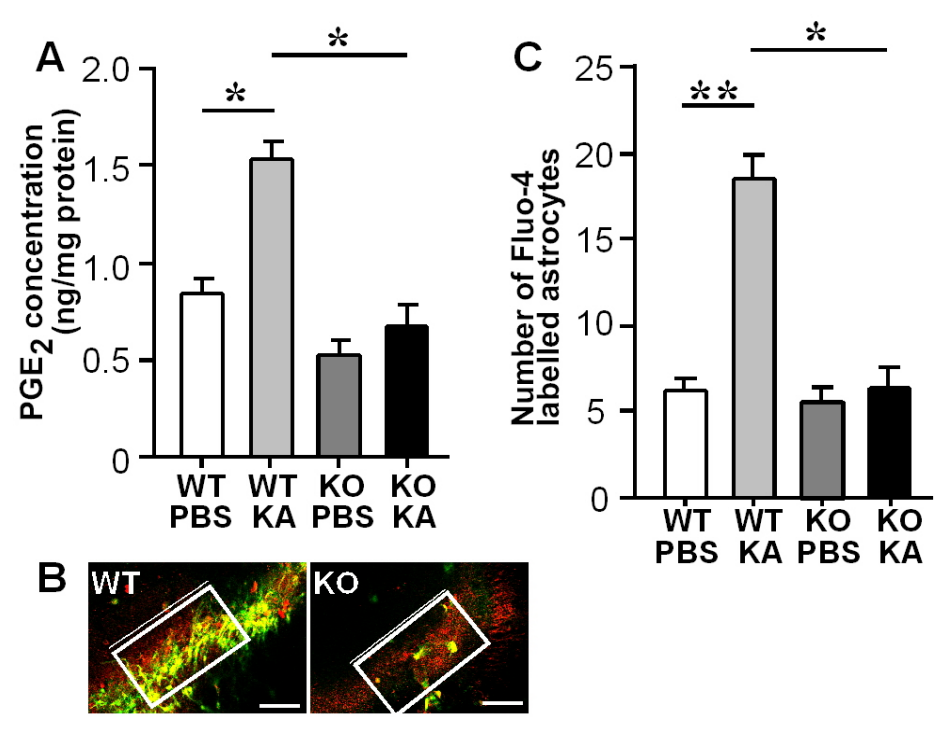


\subsection{Activation of Astrocytic EP3 Receptors by KA}

Astrocytic end-feet, shown by the GFAP-stained ring-like structures surround the blood vessels (Figure 5A,B), indicating that endothelial $\mathrm{PGE}_{2}$ directly binds to the $\mathrm{PGE}_{2}$ receptor on astrocytic end-feet. We identified the $\mathrm{PGE}_{2}$ receptor subtype responsible for the endothelial regulation of astrocytes. We examined the effects of each EP receptor antagonist and agonist on the number of Fluo-4-labeled astrocytes in the KA-treated WT and $m P G E S-1^{-1-}$ slice cultures. ONO-AE3-240 (an EP3 receptor antagonist) [33] decreased the number of Fluo-4 labeled astrocytes in the KA-treated WT slices [32]. Conversely, ONO-AE-248 (an EP3 receptor agonist) [33] increased the number of Fluo-4 labeled astrocytes in the KA-treated $m P G E S-1^{-/-}$slices, suggesting that the EP3 receptor has a crucial role in astrocytic $\mathrm{Ca}^{2+}$ elevation [32].

Figure 5. Astrocytic prostaglandin E receptor (EP)-3 is increased after KA microinjection (reprinted from ref. [19]). (A and B) Double staining with tomato lectin and an anti-GFAP antibody in the hippocampi of naive WT (A) and $m P G E S-1^{-/-}$mice (B). (C-J) Double staining with anti-EP3 and anti-GFAP antibodies in the hippocampal CA3 region of naive WT mice (C,D), WT mice at $24 \mathrm{~h}$ after KA microinjection (E,F), naive $m P G E S-1^{-/-}$mice $(\mathbf{G}, \mathbf{H})$ and $m P G E S-1^{-/-}$mice at $24 \mathrm{~h}$ after KA microinjection $(\mathbf{I}, \mathbf{J})$. Scale bars: $5 \mu \mathrm{m}$ in $\mathbf{A}, \mathbf{B}, \mathbf{D}, \mathbf{F}, \mathbf{H}, \mathbf{J} ; 50 \mu \mathrm{m}$ in $\mathbf{C}, \mathbf{E}, \mathbf{G}, \mathbf{I}$.
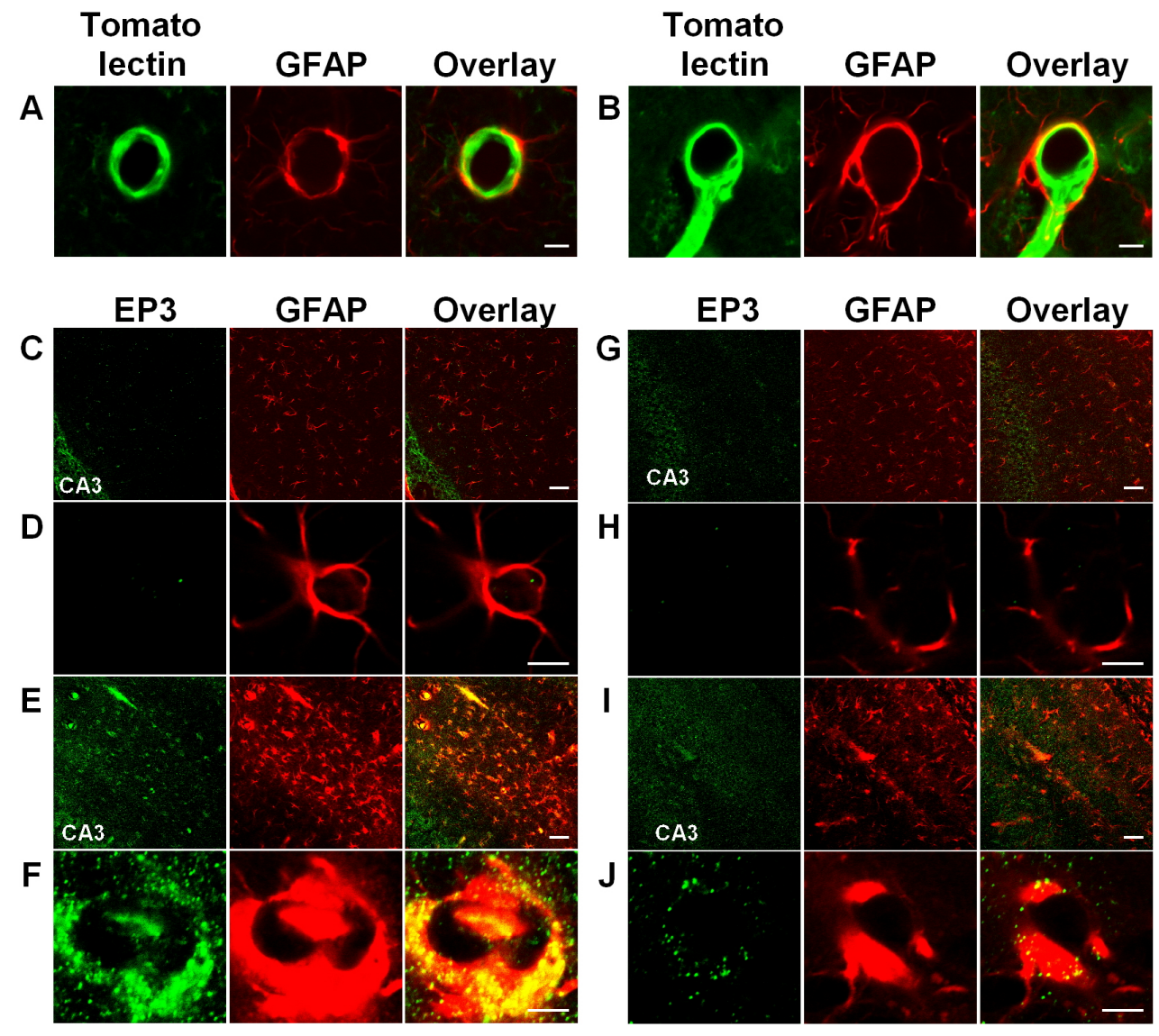

EP3 immunoreactivity is rarely detected in the end-feet in naive mice (Figure 5C,D,G,H); however, it is enhanced in the WT end-feet with swelling after KA injection (Figure 5E,F). In the $m P G E S-1^{-/-}$ mice, the end-feet also show swelling, but the EP3 immunoreactivity is not increased as much as in the 
WT mice (Figure 5I,J). These results indicate that the EP3 receptor is locally induced by KA in hippocampal astrocytes, which may receive $\mathrm{PGE}_{2}$ from endothelial cells. Preceding publications have already shown that EP3 mRNA is expressed in cultured astrocytes [34], and EP3 protein is induced in astrocytomas by interleukin-1 $\beta$ [35]. These findings indicate that astrocytic EP3 receptors may be upregulated under pathological conditions, and endothelial $\mathrm{PGE}_{2}$ may directly activate $\mathrm{EP} 3$ receptors on astrocytic end-feet, not distant neuronal EP receptors in neurotoxic brain diseases, such as epileptic seizures.

\subsection{Enhanced Glutamate Release and Neuronal Damage by Endothelial $P G E_{2}$}

In addition to astrocytic $\left[\mathrm{Ca}^{2+}\right]_{\mathrm{i}}$ elevation, we observed that the level of glutamate release was drastically enhanced in the WT slices by KA for $17 \mathrm{~h}$, but not in the $m P G E S-1^{-/}$slices [32]. To verify whether mPGES-1 regulates hippocampal neuronal death via glutamate release, we stained the cells with propidium iodide (PI) and then calculated the fluorescence ratio of the PI uptake $\left(F_{p} / F_{p i}\right)$ by dividing the fluorescence within the region of interest by that of the unstained region. The results show a greater degree of PI incorporation into the CA3 region of the WT slices than into that of the $m P G E S-1^{-/-}$slices [32]. This significant increase in $F_{p} / F_{p i}$ in the WT slices suggests that neuronal injury may be enhanced by mPGES-1, which controls the $\mathrm{Ca}^{2+}$-dependent glutamate release from astrocytes.

To validate the above findings on the endogenous $\mathrm{PGE}_{2}$, we added exogenous $\mathrm{PGE}_{2}$ to the $m P G E S-1^{-/-}$slices. The application of $5 \mu \mathrm{M} \mathrm{PGE}_{2}$ enhanced the astrocytic $\left[\mathrm{Ca}^{2+}\right]_{\mathrm{i}}$ levels, particularly around the CA3 stratum radiatum, and also increased the number of Fluo-4 labeled astrocytes [32]. Moreover, $\mathrm{PGE}_{2}$ caused an increase in the glutamate concentration and exacerbated the neuronal damage in the CA3 region, but not in the CA1 region [32]. These results indicate that the $\mathrm{PGE}_{2}$ derived from mPGES-1 modulates KA-induced neuronal injury by elevating the astrocytic $\left[\mathrm{Ca}^{2+}\right]_{\mathrm{i}}$ levels. Moreover, we confirmed whether exogenous $\mathrm{PGE}_{2}$ increases the $\left[\mathrm{Ca}^{2+}\right]_{\mathrm{i}}$ levels in cultured neurons, because a $\left[\mathrm{Ca}^{2+}\right]_{\mathrm{i}}$ increase in neurons might cause neuronal damage. We found that $\mathrm{PGE}_{2}$ could raise the $\left[\mathrm{Ca}^{2+}\right]_{\mathrm{i}}$ levels in neurons co-cultured with astrocytes, but not without astrocytes (unpublished data). In addition, the $\left[\mathrm{Ca}^{2+}\right]_{i}$ increase in neurons was found to follow the $\left[\mathrm{Ca}^{2+}\right]_{i}$ increase in astrocytes (unpublished data). These results suggest that $\mathrm{PGE}_{2}$ indirectly increases the neuronal $\left[\mathrm{Ca}^{2+}\right]_{\mathrm{i}}$ levels via the astrocytic $\left[\mathrm{Ca}^{2+}\right]_{\mathrm{i}}$ increase and subsequent glutamate release. Finally, we tested whether this $\mathrm{PGE}_{2}$-evoked glutamate release from astrocytes occurs in a $\mathrm{Ca}^{2+}$-dependent manner.

\section{5. $\mathrm{Ca}^{2+}$-Dependent Glutamate Release}

A membrane-permeable $\mathrm{Ca}^{2+}$ chelator, BAPTA-AM, was applied to the slices. BAPTA-AM diminished the increase in the $\left[\mathrm{Ca}^{2+}\right]_{\mathrm{i}}$ levels in the astrocytes in the WT slice and abolished the increase in glutamate concentration [32]. Moreover, BAPTA-AM partially ameliorated the neuronal damage in the $\mathrm{CA} 3$ region, but not in the $\mathrm{CA} 1$ region, suggesting that $\mathrm{CA} 3$ neuronal damage is locally regulated by $\mathrm{Ca}^{2+}$-dependent glutamate release from neighboring astrocytes [32].

Taken together, these results suggest that the $\mathrm{PGE}_{2}$ produced by endothelial mPGES- 1 activates the astrocytic EP3 receptor to elevate the $\left[\mathrm{Ca}^{2+}\right]_{\mathrm{i}}$ levels in astrocytes, causing $\mathrm{Ca}^{2+}$-dependent glutamate release and leading to neuronal injury (Figure 6) [32]. 
Figure 6. Schematic diagram of the endothelial regulation of neural damage after treatment with KA.

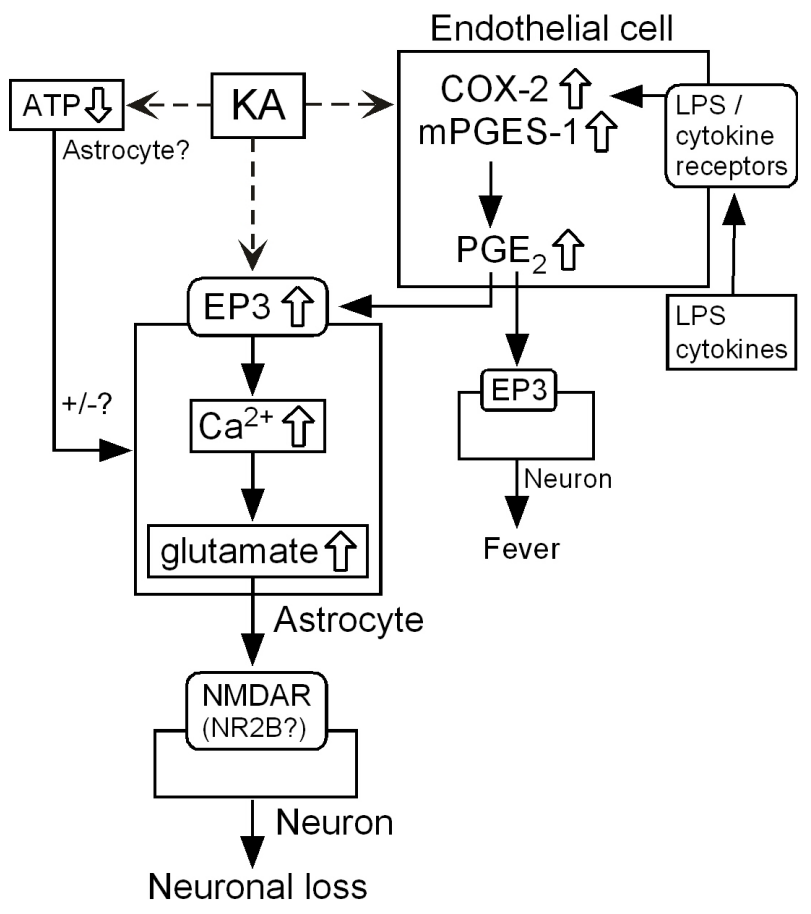

\subsection{Intercellular Signaling among Endothelia, Astrocytes and Neurons}

Accumulating evidence suggests that neuron-to-astrocyte signaling regulates arterial blood flow in the brain [22,36,37]. Conversely, there is also mounting evidence for dynamic astrocyte-to-neuron interactions, for example, astrocytes modulate synaptic transmission [28-30]. These interactions are also involved in neuronal synchrony [38] and epileptic discharges [39,40], which contribute to a delayed neuronal loss after seizures [31]. In this review, we propose an advanced mechanism for excitotoxicity via vascular endothelial cell that controls astrocyte-to-neuron signaling.

We demonstrate that endothelial mPGES-1 regulates $\mathrm{Ca}^{2+}$ signaling in astrocytes and $\mathrm{Ca}^{2+}$-dependent glutamate release from astrocytes, consistent with the finding that application of exogenous $\mathrm{PGE}_{2}$ propagates astrocytic $\mathrm{Ca}^{2+}$ waves and evokes $\mathrm{Ca}^{2+}$-dependent glutamate release from astrocytes [27]. However, as the application of $\mathrm{PGE}_{2}$ alone did not increase astrocytic $\left[\mathrm{Ca}^{2+}\right]_{\mathrm{i}}$ levels in our experimental system (data not shown), $\mathrm{PGE}_{2}$ may require another factor, such as a concomitant activation of astrocytic EP3, to elevate $\left[\mathrm{Ca}^{2+}\right]_{i}$ levels in astrocytes after KA treatment. Furthermore, it has been shown that $\mathrm{PGE}_{2}$ barely increases $\left[\mathrm{Ca}^{2+}\right]_{i}$ levels in neurons (unpublished data) and cannot evoke neuronal current directly [41], suggesting that endothelial $\mathrm{PGE}_{2}$ may specifically regulate astrocytes.

In addition to $\mathrm{PGE}_{2}, \mathrm{ATP}$ and related purine derivatives are known transmitters that are released from astrocytes, and they have been shown to depress astrocytes and neurons [42]. There is still controversy over the ATP function, because other groups claim that ATP stimulates $\mathrm{Ca}^{2+}$-dependent glutamate release from astrocytes via the $\mathrm{P} 2 \mathrm{Y} 1$ receptor and propagates $\mathrm{Ca}^{2+}$ oscillations to neighboring astrocytes $[43,44]$, leading to neuronal excitation. We find a reduction in the ATP concentration in the slices treated with KA for $17 \mathrm{~h}$. Previous studies also showed that the systemic 
administration of KA causes an ATP decrease in the rat hippocampus [45,46]. Further detailed investigation is needed to infer the role of ATP in the KA-induced neurotoxicity.

Hippocampal neurons are vulnerable to glutamate, and it is thought to be mediated by $N$-methyl-D-aspartate (NMDA) receptors (NMDARs) [47]. In particular, glutamate release from astrocytes activates extrasynaptic NMDAR NR2B, which induces neuronal currents [31] or triggers neuronal cell death [31,48] [49], suggesting that extrasynaptic NR2B receptors have important roles in the neurotoxicity caused by the glutamate released from astrocytes. Conversely, neuronal glutamate activates astrocytic mGluR5 to cause an increase in $\left[\mathrm{Ca}^{2+}\right]_{i}$ levels in astrocytes, which may in turn release glutamate and feedback to extrasynaptic NMDAR NR2B [31]. Thus, the neuron-astrocyte circuit may amplify the glutamate signaling, which aggravates neuronal excitotoxicity following seizures.

The results described here indicate that brain endothelial cells are not merely a physiological barrier between the blood and brain, but may also act as a signal transducer or amplifier. In particular, endothelial cells may be active under pathological conditions, such as in epileptic seizure. In response to such insults, endothelial cells would continuously supply a large amount of $\mathrm{PGE}_{2}$ to astrocytes, which would in turn affect neurons. The interaction among neurons, astrocytes and endothelial cells may be a key for investigating the processes of neuropathological disorders.

\section{Conclusions}

We find that $\mathrm{PGE}_{2}$ is synthesized by inducible mPGES-1 in cooperation with COX-2 in vascular endothelial cells in response to KA treatment. Moreover, endothelial $\mathrm{PGE}_{2}$ activates astrocytic the EP3 receptor to elevate $\left[\mathrm{Ca}^{2+}\right]_{i}$ levels in astrocytes, causing $\mathrm{Ca}^{2+}$-dependent glutamate release and, subsequently, stimulating neuronal damage. This is a first clarification of a mechanism for neuronal damage regulated by endothelial cells; therefore, this review emphasizes that brain endothelial cells act as a signal transducer or amplifier, especially, under pathological conditions, such as epileptic seizure. The analysis of the interactions among neurons, astrocytes and endothelial cells provides a better understanding of the processes of neuropathological disorders and will facilitate the development of new treatments.

\section{Acknowledgments}

This work was supported by KAKENHI (22591139) from the Japan Society for the Promotion of Science. We acknowledge Neuroscience Research (Elsevier Ltd.), the Journal of Neuroscience Research (Wiley-Liss, Inc.) and Neurochemistry International (Elsevier Ltd.) for their permission to reproduce figures from our published manuscripts.

\section{Conflict of Interest}

The authors declare no conflict of interest. 


\section{References}

1. Matsumura, K.; Watanabe, Y.; Onoe, H.; Hayaishi, O. High density of prostaglandin E2 binding sites in the anterior wall of the 3rd ventricle: A possible site of its hyperthermic action. Brain Res. 1990, 533, 147-151.

2. Takemiya, T.; Suzuki, K.; Sugiura, H.; Yasuda, S.; Yamagata, K.; Kawakami, Y.; Maru, E. Inducible brain COX-2 facilitates the recurrence of hippocampal seizures in mouse rapid kindling. Prostaglandins Other Lipid Mediat. 2003, 71, 205-216.

3. Sasaki, T.; Kitagawa, K.; Yamagata, K.; Takemiya, T.; Tanaka, S.; Omura-Matsuoka, E.; Sugiura, S.; Matsumoto, M.; Hori, M. Amelioration of hippocampal neuronal damage after transient forebrain ischemia in cyclooxygenase-2-deficient mice. J. Cereb. Blood Flow Metab. 2004, 24, 107-113.

4. Cao, C.; Matsumura, K.; Shirakawa, N.; Maeda, M.; Jikihara, I.; Kobayashi, S.; Watanabe, Y. Pyrogenic cytokines injected into the rat cerebral ventricle induce cyclooxygenase- 2 in brain endothelial cells and also upregulate their receptors. Eur. J. Neurosci. 2001, 13, 1781-1790.

5. Cao, C.; Matsumura, K.; Yamagata, K.; Watanabe, Y. Endothelial cells of the rat brain vasculature express cyclooxygenase- 2 mRNA in response to systemic interleukin-1 beta: A possible site of prostaglandin synthesis responsible for fever. Brain Res. 1996, 733, 263-272.

6. Cao, C.; Matsumura, K.; Yamagata, K.; Watanabe, Y. Induction by lipopolysaccharide of cyclooxygenase-2 mRNA in rat brain; its possible role in the febrile response. Brain Res. 1995, 697, 187-196.

7. Matsumura, K.; Cao, C.; Ozaki, M.; Morii, H.; Nakadate, K.; Watanabe, Y. Brain endothelial cells express cyclooxygenase-2 during lipopolysaccharide-induced fever: Light and electron microscopic immunocytochemical studies. J. Neurosci. 1998, 18, 6279-6289.

8. Yamagata, K.; Andreasson, K.I.; Kaufmann, W.E.; Barnes, C.A.; Worley, P.F. Expression of a mitogen-inducible cyclooxygenase in brain neurons: Regulation by synaptic activity and glucocorticoids. Neuron 1993, 11, 371-386.

9. Takemiya, T.; Yamagata, K. Chapter 4. Effects of COX-2 Inhibitors on Brain Diseases. In Trends in COX-2 Inhibitor Research; Howardell, M., Ed.; Nova Science Publishers: New York, NY, USA, 2007; pp. 47-75.

10. Takemiya, T.; Matsumura, K.; Yamagata, K. Roles of prostaglandin synthesis in excitotoxic brain diseases. Neurochem. Int. 2007, 51, 112-120.

11. Takemiya, T.; Yamagata, K. Chapter 3. The Modulatory Role of COX-2 and Prostaglandins in Brain Diseases. In Prostaglandins: New Research; Bronson, C., Ed.; Nova Science Publishers: New York, NY, USA, 2006; pp. 63-89.

12. Takemiya, T.; Maehara, M.; Matsumura, K.; Yasuda, S.; Sugiura, H.; Yamagata, K. Prostaglandin E2 produced by late induced COX-2 stimulates hippocampal neuron loss after seizure in the CA3 region. Neurosci. Res. 2006, 56, 103-110.

13. Yamagata, K.; Matsumura, K.; Inoue, W.; Shiraki, T.; Suzuki, K.; Yasuda, S.; Sugiura, H.; Cao, C.; Watanabe, Y.; Kobayashi, S. Coexpression of microsomal-type prostaglandin E synthase with cyclooxygenase-2 in brain endothelial cells of rats during endotoxin-induced fever. J. Neurosci. 2001, 21, 2669-2677. 
14. Engblom, D.; Saha, S.; Engstrom, L.; Westman, M.; Audoly, L.P.; Jakobsson, P.J.; Blomqvist, A. Microsomal prostaglandin E synthase-1 is the central switch during immune-induced pyresis. Nat. Neurosci. 2003, 6, 1137-1138.

15. Trebino, C.E.; Stock, J.L.; Gibbons, C.P.; Naiman, B.M.; Wachtmann, T.S.; Umland, J.P.; Pandher, K.; Lapointe, J.M.; Saha, S.; Roach, M.L.; et al. Impaired inflammatory and pain responses in mice lacking an inducible prostaglandin E synthase. Proc. Natl. Acad. Sci. USA 2003, 100, 9044-9049.

16. Inoue, W.; Matsumura, K.; Yamagata, K.; Takemiya, T.; Shiraki, T.; Kobayashi, S. Brain-specific endothelial induction of prostaglandin $\mathrm{E}(2)$ synthesis enzymes and its temporal relation to fever. Neurosci. Res. 2002, 44, 51-61.

17. Ek, M.; Engblom, D.; Saha, S.; Blomqvist, A.; Jakobsson, P.J.; Ericsson-Dahlstrand, A. Inflammatory response: Pathway across the blood-brain barrier. Nature 2001, 410, 430-431.

18. Cavalheiro, E.A.; Riche, D.A.; Le Gal La Salle, G. Long-term effects of intrahippocampal kainic acid injection in rats: A method for inducing spontaneous recurrent seizures. Electroencephalogr. Clin. Neurophysiol. 1982, 53, 581-589.

19. Takemiya, T.; Matsumura, K.; Sugiura, H.; Maehara, M.; Yasuda, S.; Uematsu, S.; Akira, S.; Yamagata, K. Endothelial microsomal prostaglandin E synthase-1 exacerbates neuronal loss induced by kainate. J. Neurosci. Res. 2010, 88, 381-390.

20. Uematsu, S.; Matsumoto, M.; Takeda, K.; Akira, S. Lipopolysaccharide-dependent prostaglandin $\mathrm{E}(2)$ production is regulated by the glutathione-dependent prostaglandin $\mathrm{E}(2)$ synthase gene induced by the Toll-like receptor 4/MyD88/NF-IL6 pathway. J. Immunol. 2002, 168, 5811-5816.

21. Parri, R.; Crunelli, V. An astrocyte bridge from synapse to blood flow. Nat. Neurosci. 2003, 6, 5-6.

22. Zonta, M.; Angulo, M.C.; Gobbo, S.; Rosengarten, B.; Hossmann, K.A.; Pozzan, T.; Carmignoto, G. Neuron-to-astrocyte signaling is central to the dynamic control of brain microcirculation. Nat. Neurosci. 2003, 6, 43-50.

23. Mulligan, S.J.; MacVicar, B.A. Calcium transients in astrocyte endfeet cause cerebrovascular constrictions. Nature 2004, 431, 195-199.

24. Turrin, N.P.; Rivest, S. Innate immune reaction in response to seizures: Implications for the neuropathology associated with epilepsy. Neurobiol. Dis. 2004, 16, 321-334.

25. Ciceri, P.; Zhang, Y.; Shaffer, A.F.; Leahy, K.M.; Woerner, M.B.; Smith, W.G.; Seibert, K.; Isakson, P.C. Pharmacology of celecoxib in rat brain after kainate administration. J. Pharmacol. Exp. Ther. 2002, 302, 846-852.

26. Janzer, R.C.; Raff, M.C. Astrocytes induce blood-brain barrier properties in endothelial cells. Nature 1987, 325, 253-257.

27. Bezzi, P.; Carmignoto, G.; Pasti, L.; Vesce, S.; Rossi, D.; Rizzini, B.L.; Pozzan, T.; Volterra, A. Prostaglandins stimulate calcium-dependent glutamate release in astrocytes. Nature 1998, 391, 281-285.

28. Volterra, A.; Steinhauser, C. Glial modulation of synaptic transmission in the hippocampus. Glia 2004, 47, 249-257.

29. Haydon, P.G.; Carmignoto, G. Astrocyte control of synaptic transmission and neurovascular coupling. Physiol. Rev. 2006, 86, 1009-1031. 
30. Perea, G.; Araque, A. Astrocytes potentiate transmitter release at single hippocampal synapses. Science 2007, 317, 1083-1086.

31. Ding, S.; Fellin, T.; Zhu, Y.; Lee, S.Y.; Auberson, Y.P.; Meaney, D.F.; Coulter, D.A.; Carmignoto, G.; Haydon, P.G. Enhanced astrocytic $\mathrm{Ca}^{2+}$ signals contribute to neuronal excitotoxicity after status epilepticus. J. Neurosci. 2007, 27, 10674-10684.

32. Takemiya, T.; Matsumura, K.; Sugiura, H.; Yasuda, S.; Uematsu, S.; Akira, S.; Yamagata, K. Endothelial microsomal prostaglandin E synthase-1 facilitates neurotoxicity by elevating astrocytic $\mathrm{Ca}^{2+}$ levels. Neurochem. Int. 2011, 58, 489-496.

33. Amano, H.; Hayashi, I.; Endo, H.; Kitasato, H.; Yamashina, S.; Maruyama, T.; Kobayashi, M.; Satoh, K.; Narita, M.; Sugimoto, Y.; et al. Host prostaglandin E(2)-EP3 signaling regulates tumor-associated angiogenesis and tumor growth. J. Exp. Med. 2003, 197, 221-232.

34. Kitanaka, J.; Hashimoto, H.; Gotoh, M.; Kondo, K.; Sakata, K.; Hirasawa, Y.; Sawada, M.; Suzumura, A.; Marunouchi, T.; Matsuda, T.; et al. Expression pattern of messenger RNAs for prostanoid receptors in glial cell cultures. Brain Res. 1996, 707, 282-287.

35. Waschbisch, A.; Fiebich, B.L.; Akundi, R.S.; Schmitz, M.L.; Hoozemans, J.J.; Candelario-Jalil, E.; Virtainen, N.; Veerhuis, R.; Slawik, H.; Yrjanheikki, J.; et al. Interleukin-1 beta-induced expression of the prostaglandin E-receptor subtype EP3 in U373 astrocytoma cells depends on protein kinase C and nuclear factor-kappaB. J. Neurochem. 2006, 96, 680-693.

36. Takano, T.; Tian, G.F.; Peng, W.; Lou, N.; Libionka, W.; Han, X.; Nedergaard, M. Astrocyte-mediated control of cerebral blood flow. Nat Neurosci. 2006, 9, 260-267.

37. Iadecola, C.; Nedergaard, M. Glial regulation of the cerebral microvasculature. Nat. Neurosci. 2007, 10, 1369-76.

38. Fellin, T.; Pascual, O.; Gobbo, S.; Pozzan, T.; Haydon, P.G.; Carmignoto, G. Neuronal synchrony mediated by astrocytic glutamate through activation of extrasynaptic NMDA receptors. Neuron 2004, 43, 729-743.

39. Kang, N.; Xu, J.; Xu, Q.; Nedergaard, M.; Kang, J. Astrocytic glutamate release-induced transient depolarization and epileptiform discharges in hippocampal CA1 pyramidal neurons. $J$. Neurophysiol. 2005, 94, 4121-4130.

40. Tian, G.F.; Azmi, H.; Takano, T.; Xu, Q.; Peng, W.; Lin, J.; Oberheim, N.; Lou, N.; Wang, X.; Zielke, H.R.; et al. An astrocytic basis of epilepsy. Nat. Med. 2005, 11, 973-981.

41. Sanzgiri, R.P.; Araque, A.; Haydon, P.G. Prostaglandin E(2) stimulates glutamate receptor-dependent astrocyte neuromodulation in cultured hippocampal cells. J. Neurobiol. 1999, $41,221-229$.

42. Ortinau, S.; Laube, B.; Zimmermann, H. ATP inhibits NMDA receptors after heterologous expression and in cultured hippocampal neurons and attenuates NMDA-mediated neurotoxicity. J. Neurosci. 2003, 23, 4996-5003.

43. Jeremic, A.; Jeftinija, K.; Stevanovic, J.; Glavaski, A.; Jeftinija, S. ATP stimulates calcium-dependent glutamate release from cultured astrocytes. J. Neurochem. 2001, 77, 664-675.

44. Domercq, M.; Brambilla, L.; Pilati, E.; Marchaland, J.; Volterra, A.; Bezzi, P. P2Y1 receptor-evoked glutamate exocytosis from astrocytes: Control by tumor necrosis factor-alpha and prostaglandins. J. Biol. Chem. 2006, 281, 30684-30696. 
45. Vezzani, A.; Sangalli, L.; Wu, H.Q.; Schwarcz, R. ATP as a marker of excitotoxin-induced nerve cell death in vivo. J. Neural. Transm. 1987, 70, 349-56.

46. Kobayashi, S.; Kikuchi, H.; Ishikawa, M.; Hashimoto, K. Regional changes of tissue pH and ATP content in rat brain following systemic administration of kainic acid. Brain Res. 1990, 514, 352-354.

47. Kambe, Y.; Nakamichi, N.; Georgiev, D.D.; Nakamura, N.; Taniura, H.; Yoneda, Y. Insensitivity to glutamate neurotoxicity mediated by NMDA receptors in association with delayed mitochondrial membrane potential disruption in cultured rat cortical neurons. J. Neurochem. 2008, 105, 1886-1900.

48. Hardingham, G.E.; Fukunaga, Y.; Bading, H. Extrasynaptic NMDARs oppose synaptic NMDARs by triggering CREB shut-off and cell death pathways. Nat. Neurosci. 2002, 5, 405-414.

49. Vizi, E.S.; Fekete, A.; Karoly, R.; Mike, A. Non-synaptic receptors and transporters involved in brain functions and targets of drug treatment. Br. J. Pharmacol. 2010, 160, 785-809.

(C) 2013 by the authors; licensee MDPI, Basel, Switzerland. This article is an open access article distributed under the terms and conditions of the Creative Commons Attribution license (http://creativecommons.org/licenses/by/3.0/). 